\title{
Social Psychological Review to Agricultural Modernization for the Improvement of Rice Production in Anggeraja Sub-district, South Sulawesi, Indonesia
}

\author{
Abdul Rahman Pilang \\ ${ }^{1}$ BOSOWA 45 University of Makassar, Indonesia \\ Correspondence: Abdul Rahman Pilang, University 45 of Makassar, Indonesia. E-mail: agustitantu@yahoo.com
}

Received: July 8, 2013 Accepted: August 4, 2014 Online Published: September 29, 2014

doi:10.5539/ass.v10n19p139 URL: http://dx.doi.org/10.5539/ass.v10n19p139

\begin{abstract}
The study aims to find out social psychological factor to agricultural modernization in improving rice production in Anggeraja Sub-district, Enrekang Regency, South Sulawesi. Methods applied herein are questionnaire, interview, documentation, and observational methods. The finding indicates that educated farmers perform the more positive participation compared to uneducated farmers either in attending the arranged counseling or executing the instructions given by officers. Both hypotheses reflect farmer's attitude to agricultural modernization; thus, hypothesis proposing that "success and failure of agricultural modernization in Anggeraja Sub-district is affected by attitude of farmers therein" is also acceptable.
\end{abstract}

Keywords: social psychological, agricultural modernization, rice production, South Sulawesi

\section{Introduction}

Indonesia as a newly developing nation does not free from population problem like what have been faced by most of developing nations. Even, based on the number of population, Indonesia is in the list of top five populous countries of the world after China, India, Soviet Union and USA. When increase in population grows rapidly, increase in agricultural land as foodstuff-producing land for human's staple food is too slow. Moreover, intensification is also unable to increase the product twice such as what happens to increase in population. Thereby, one of problem solving taken by the government, other than birth control through family planning system (Keluarga Berencana or KB), implementation of agricultural modernization is the best choice.

Implementation of agricultural modernization as an integral part of national development is not all that easy when the program is arranged. Implementation of the program is a complex duty due to lots of involved factors therein. In every year, the condition has to be formed in such way to ensure increase of the expected agricultural production.

In connection with the implementation of agricultural modernization executed in Anggeraja Sub-district as a new method for people therein, it is possible that the implementation will face obstacle. It has been known that traditional society like farmers in Anggeraja Sub-district is introvert people and they do not interested in new things. Above all when the new thing goes against their custom. For sure, it is just an obstacle to agricultural modernization in particular and to the development in general.

For making agricultural modernization success, such problem has to be solved first, especially if it relates to social psychological state; "people's attitude", for example, has to be observed since it is the key to success. Traditionalism attitude, mental even moralities worshiping traditional custom a lot are things which shall be prevented. Human being as a part of society has to be mobilized; if at the previous time, human belongs to the object of development, from now on, human is the subject who develops. Since it is only this kind of society who will be able to realize the development and modernity.

\section{Research Procedure}

In an effort of proving, a number of data are required. To obtain the intended data, despite the newest method used herein, problems relating to area or object have to be made concrete. Therefore, to make a directive and efficient study, the following are steps to be taken: 


\subsection{Population}

Population is a number of planned residents used as the target of study; it is commonly known as universum. Population is a least number of residents or individual who have similar character. In connection to the upcoming study, object of the study is Anggeraja Sub-district and its population, i.e. all participants of agricultural modernization in this sub-district by 3.306 people.

\subsection{Sample}

To research population as a whole, it needs time, energy and cost. Due to ability constraints, the study is carried out by using sampling technique. Other consideration in executing sampling method is that condition of population is not too different between one and others. It is understandable that common villagers in Indonesia have some similar matters in their attitude. Indonesia is agrarian country where most of the citizens make their life dependent on agricultural products.

It is undeniable that there has never been found a hundred percent homogeneous citizens in the world, but this has been figured out. Therefore, data processing is taken by statistics where factors of deviance have had problem solving determined mathematically.

Sampling technique explained herein are area and sampling and stratified sampling.

a. Area sampling is a sampling technique in which sample of individual or subject is determined based on its residential place. The choosen sample area herein is Lakawan and Metaran Villages. Motives in determining these two villages as the sample are follows:

- Lukawan Village is a village where center of the sub-district is set therein. The residents work as farmer, merchant and employee. In fact, this classification is not an absolute classification, since average employees and merchants are also farmer. Residents in this village are more developed people than other villages. By this consideration, farmer of this village may represent likely-developed farmers existing in other three villages.

- Mataran Village, based in less than $7 \mathrm{~km}$ from the center of sub-district, is expected of being able to represent other villages which in general are rather far away from the center of sub-district. Almost all of the residents are uneducated farmers.

b. Stratified sampling is a method to determine the sample by dividing all population into categories or levels. What has to be taken into consideration is that the existing farmers have stratified educational background starting from illiterate, elementary school, junior high school or above. Despite of approach method of agricultural modernization applied in the study, these three steps are also applied; giving command/teaching method, demonstration, and farmers grouping methods. Determination on participants of agricultural modernization takes place in phases based on implementation steps of every approach method in the program.

\section{Research Method}

\subsection{Questionnaire Method}

Questionnaire method is an instrument which is commonly utilized to collect data for a study on social problem by means of a sequence of questions. Questionnaire is meant to be a method to acquire answer based on the question by using answer sheet filled by the respondent. Even if the method has been used as main method, it does not mean that the method has no weakness or debility. In revealing emotional perception, mind and other psychological issues, it is not a simple thing. Decision making, inward feeling, decision to deal or no deal on something is a complex psychological process.

Amount of distributed questionnaire is 250 sheets; but, in order to simplify data processing, it will only 200 sheets to be processed, while the remaining are reserved sheets either the incorrect or other excess sheets. There are some obstacles in distributing the questionnaire like some respondents who cannot read and write. Then, it is resolved by giving explanation in local language and assisting respondent to fill the questionnaire.

\subsection{Interview Method}

As proposed above that in revealing issue or data relating to personal state of someone will not enough if it uses questionnaire method only. Thus, some supporting methods are also applied such as interview method. It is seen as data collection method by proposing unilateral question and answer conducted systematically which based on the objectives of the study. 
During the process of interview, two respondents with different status are interviewed. Interviewer, in this case, acts on behalf of "information hunter", while the other is informant required for the study. Interviewer and interviewee, during this process, have to do face to face talks.

\subsection{Documentation Method}

It is a method which collects data from the existing notes, documents or reports. By means of this documentation method, data like sites of the program, number of participants from year to year as well as documents or reports relating to implementation of agricultural modernization in Anggeraja Sub-district can be acquired. Also, identity of the residents such as educational background and residence may be acquired through this documentation method.

\subsection{Observational Method}

Role of this method in the study is not as important as other methods. Observational method is meant to see the condition of farmer's plants which portrays success and failure in implementing agricultural modernization. By witnessing condition of plant, farmers will let researcher making conclusion based on the collected data.

It is necessary to know that observational method is a data collecting method through direct and systematic observation. Ronald (1970) formulates observation as follows: Observation is an investigation conducted to find out certain thing. In general, observation is carried out purposely and it utilizes investigation. Thus, this observation will be more credible to the observed matter, because it is witnessed directly. The reason is that most people will believe in things if they had witnessed it. Perhaps, the report acquires the data where the modernization runs well, but in fact, this modernization meets failure. By executing observation, possible mistakes may be solved.

\section{Findings and Discussion}

Presented data is the data obtained from questionnaire which had been distributed and from the reports on implementation of agricultural modernization. By observing the existing data, utilized data processing technique is inferential statistics through analysis of variance (ANOVA) as formulated below:

$$
\begin{aligned}
& \mathrm{DK}_{\text {tot }}=\sum x^{2} \text { tot }-\frac{\left(\sum x_{\text {tot }}\right)^{2}}{N} \\
& \mathrm{DK}_{\mathrm{b}}=\frac{\left(\sum x_{1}\right)^{2}}{n_{1}}+\frac{\left(\sum x_{2}\right)^{2}}{n_{1}}+\ldots \ldots . .+\frac{\left(\sum x_{m}\right)^{2}}{n_{m}}-\frac{\left(\sum x_{t o t}\right)^{2}}{N} \\
& \mathrm{DK}_{\mathrm{w}}=D K_{\text {tot }}-D K_{\text {ant }} \\
& \mathrm{MK}_{\mathrm{b}}=\frac{D K_{a n t}}{d b_{a n t}} M K_{b} \\
& \mathrm{~F}_{\mathrm{db}_{\mathrm{b}}} ; \mathrm{db}_{\mathrm{w}}=\frac{M K_{b}}{M K_{w}}
\end{aligned}
$$

information:

$$
\begin{array}{ll}
\mathrm{DK}_{\mathrm{tot}} & =\text { Total amount of squares. } \\
\mathrm{DK}_{\mathrm{b}} & =\text { Amount of intergroup squares. } \\
\mathrm{DK}_{\mathrm{w}} & =\text { Amount of in-group squares. } \\
\mathrm{MK}_{\mathrm{b}} & =\text { Mean of intergroup squares. } \\
\mathrm{MK}_{\mathrm{w}} & =\text { Mean of in-group squares. } \\
\mathrm{db}_{\mathrm{b}} & =\mathrm{m}-1 \\
\mathrm{db}_{\mathrm{w}} & =\mathrm{N}-\mathrm{m} \\
\mathrm{m} & =\text { Amount of groups. } \\
\mathrm{N} & =\text { Amount of individual. }
\end{array}
$$

A motive in applying ANOVA to process or analyze the data is that among various processing techniques, ANOVA is quite flexible. It is also due to technique in ANOVA. Other than applying this data processing, technique of descriptive statistics by percentage is also utilized. Below are the data which will be processed. 
Table 1. Relationship between farmer's educational background and their absence at agricultural modernization counseling

\begin{tabular}{ccccc}
\hline \multirow{2}{*}{ Educational background } & \multicolumn{3}{c}{ Attendance } & \multirow{2}{*}{ Amount } \\
\cline { 2 - 4 } & Always & Sometimes & No ever & \\
Junior high school or above & 42 & 8 & - & 50 \\
Elementary school & 50 & 19 & 6 & 75 \\
Illiterate & 30 & 37 & 8 & 75 \\
Total & 122 & 64 & 14 & 200 \\
\hline
\end{tabular}

Table 2. Worksheet to calculate $f_{0}$

\begin{tabular}{|c|c|c|c|c|c|c|c|c|c|c|c|c|c|}
\hline \multirow{3}{*}{ Educational background } & \multirow{3}{*}{$\begin{array}{c}\mathrm{X} \\
\text { code }\end{array}$} & \multicolumn{9}{|c|}{ Attendance at the counseling } & \multirow{3}{*}{$f_{\text {tot }}$} & \multirow{3}{*}{$f_{\mathrm{x}_{\mathrm{tot}}}$} & \multirow{3}{*}{$f \mathrm{x}^{2}$ tot } \\
\hline & & \multicolumn{3}{|c|}{ Always } & \multicolumn{3}{|c|}{ Sometimes } & \multicolumn{3}{|c|}{ Never } & & & \\
\hline & & $f$ & $f x_{1}$ & $f x_{1}^{2}$ & $f$ & $f x_{2}$ & $f x_{2}^{2}$ & $f$ & $f x_{3}$ & $f x_{3}^{2}$ & & & \\
\hline Junior high school or above & 2 & 42 & 84 & 168 & 8 & 16 & 32 & - & - & - & 50 & 100 & 200 \\
\hline Elementary school & 1 & 50 & 50 & 50 & 19 & 19 & 19 & 6 & 6 & 6 & 75 & 75 & 75 \\
\hline Illiterate & 0 & 30 & 0 & 0 & 37 & 0 & 0 & 8 & 0 & 0 & 75 & 0 & 0 \\
\hline Total & - & 122 & 134 & 218 & 64 & 35 & 51 & 14 & 6 & 6 & 200 & 175 & 275 \\
\hline
\end{tabular}

$$
\begin{aligned}
\mathrm{DK}_{\mathrm{tot}} & =\sum f x_{\text {tot }}-\frac{\left(\sum f x_{\text {tot }}\right)^{2}}{N}=275-\frac{(175)^{2}}{200}=275-153,125=121,875 \\
\mathrm{DK}_{\mathrm{b}} & =\frac{\left(\sum f x_{1}\right)}{n_{1}}+\frac{\left(\sum f x_{2}\right)^{2}}{n^{2}}+\frac{\left(\sum f x_{3}\right)^{2}}{n_{3}}+\frac{\left(\sum f x_{\text {tot }}\right)^{2}}{N}= \\
& =\frac{(134)^{2}}{122}+\frac{(35)^{2}}{64}+\frac{(6)^{2}}{14} \frac{(175)^{2}}{200}=147.180+19.141+2.571-153.125= \\
& =168.892-153.125=15.767 \\
\mathrm{DK}_{\mathrm{w}} & =D K_{\text {tot }}-D K_{b}=121.875-15.767=106.108 \\
\mathrm{MK}_{\mathrm{b}} & =\frac{D K_{\text {ant }}}{m-1}=\frac{15,767}{2}=7,884 \\
\mathrm{MK}_{\mathrm{w}} & =\frac{D K_{\text {dal }}}{N-m}=\frac{106,180}{197}=0,539 \\
\frac{M K_{\text {ant }}}{M K_{\text {dal }}}= & \frac{7,884}{0,539}=14,627
\end{aligned}
$$

Table 3. ANOVA summary table based on the data in Table 2.

\begin{tabular}{ccccccc}
\hline Sources of variation & $\mathrm{db}$ & $\mathrm{DK}$ & $\mathrm{MK}$ & $\mathrm{F}_{\mathrm{o}}$ & $\mathrm{F}_{\mathrm{t}}$ & Significance \\
\hline Intergroup & 2 & 15.767 & 7.884 & & $5 \%$ & Significant \\
& & & & 14.627 & 3.04 & $1 \%$ \\
In-group & 197 & 106.108 & 0.539 & & 4.71 & Significant \\
Total & 199 & 121.875 & - & - & - & - \\
\hline
\end{tabular}

If the calculated $F_{o}$ is greater than theoretical $F$ either in degree of significance by $5 \%$ (3.04) or degree of significance by $1 \%$ (4.71), null hypothesis proposing that: "There is no significant effect between farmer's educational background and frequency of attendance at the counseling of agricultural modernization" is rejected. Thereby, it can be proved that farmer's educational background has significant effect to frequency of attendance at the counseling of agricultural modernization; it means that higher educational background achieved by farmer makes the farmer more frequent to attend at the arranged counseling. 
Table 4. Relationship between participation of farmer in the counseling and their comprehension on agricultural modernization

\begin{tabular}{ccccc}
\hline \multirow{2}{*}{ Attendance } & \multicolumn{3}{c}{ Degrees of comprehension } & \multirow{2}{*}{ Amount } \\
\cline { 2 - 4 } & Understand & Somewhat understand & Does not understand & \\
Always & & & 2 & 122 \\
Sometimes & 102 & 18 & 2 & 64 \\
Never & 47 & 15 & 10 & 14 \\
& - & 4 & 14 & 200 \\
\hline
\end{tabular}

Table 5. Worksheet to calculate $\mathrm{f}_{\mathrm{o}}$

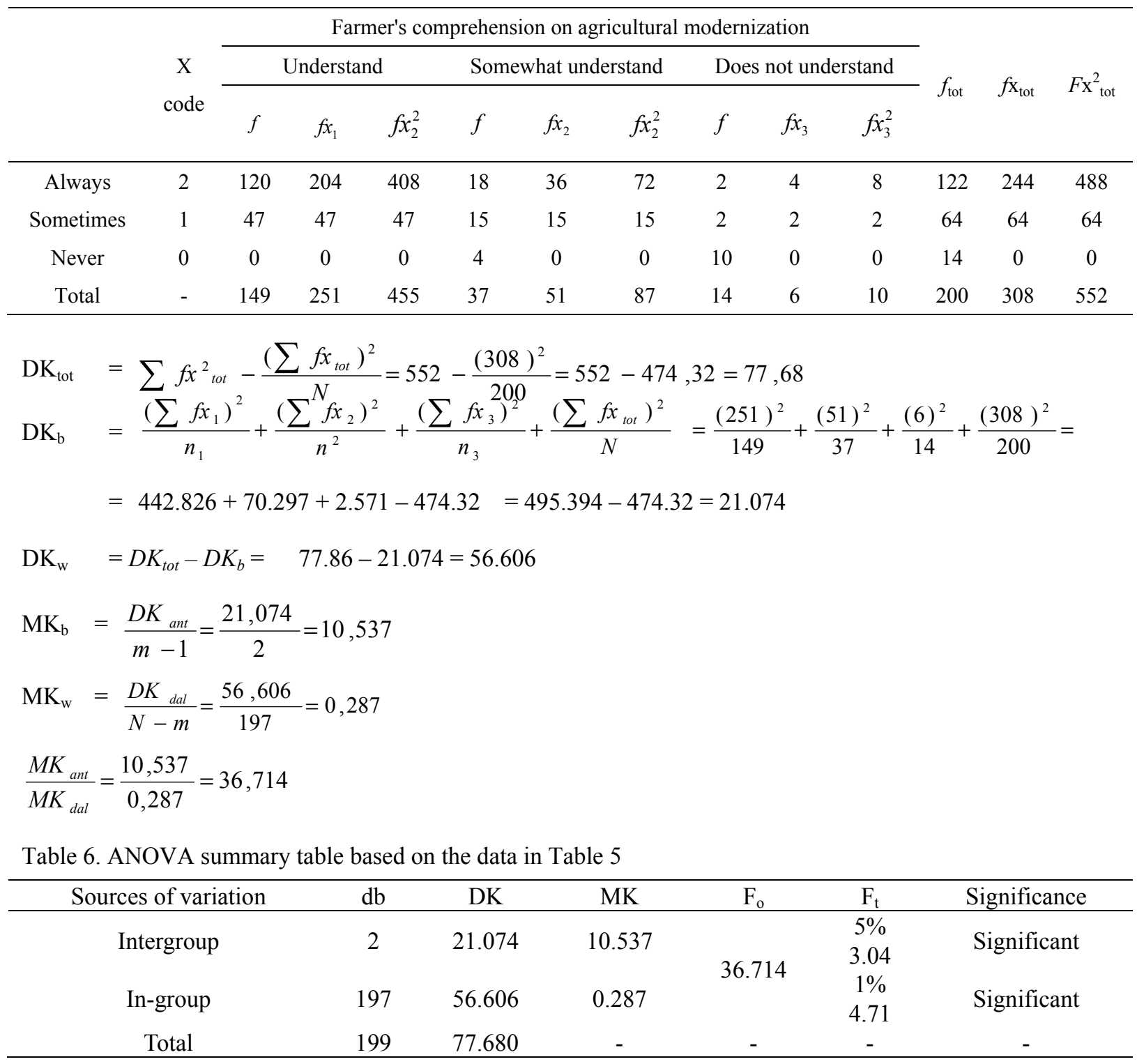

If the calculated $\mathrm{F}_{\mathrm{o}}$ (36.714) is higher than theoretical $\mathrm{F}$ either in significance level of 5\% (3.04) or significance level of $1 \%(4.71)$, null hypothesis stating that there is no influence between frequency of attending at the counseling and farmers' comprehension on agricultural modernization in Anggeraja Sub-district is rejected.

Thus, it can be proved that frequency of farmer in attending at the counseling of agricultural modernization has a significant effect on farmer's comprehension on that matter. It means that the more often involved farmers attend at the organized counseling, it will enable them to understand matters about agricultural modernization. 
Table 7. Relationship between implementation of guidance given by the counseling of agricultural modernization and farmer's comprehension on agricultural modernization

\begin{tabular}{ccccc}
\hline \multirow{2}{*}{ Implementation of guidance } & \multicolumn{2}{c}{ Farmer's comprehension } & \multirow{2}{*}{ Amount } \\
\cline { 2 - 4 } & Understand & Somewhat understand & Does not understand \\
\hline Implement all guidance & 120 & 10 & - & 130 \\
Implement guidance in part & 29 & 25 & 2 & 54 \\
Do not implement guidance at all & - & 2 & 12 & 14 \\
Total & 149 & 37 & 14 & 200 \\
\hline
\end{tabular}

Table 8 . Worksheet to calculate $\mathrm{f}_{\mathrm{o}}$

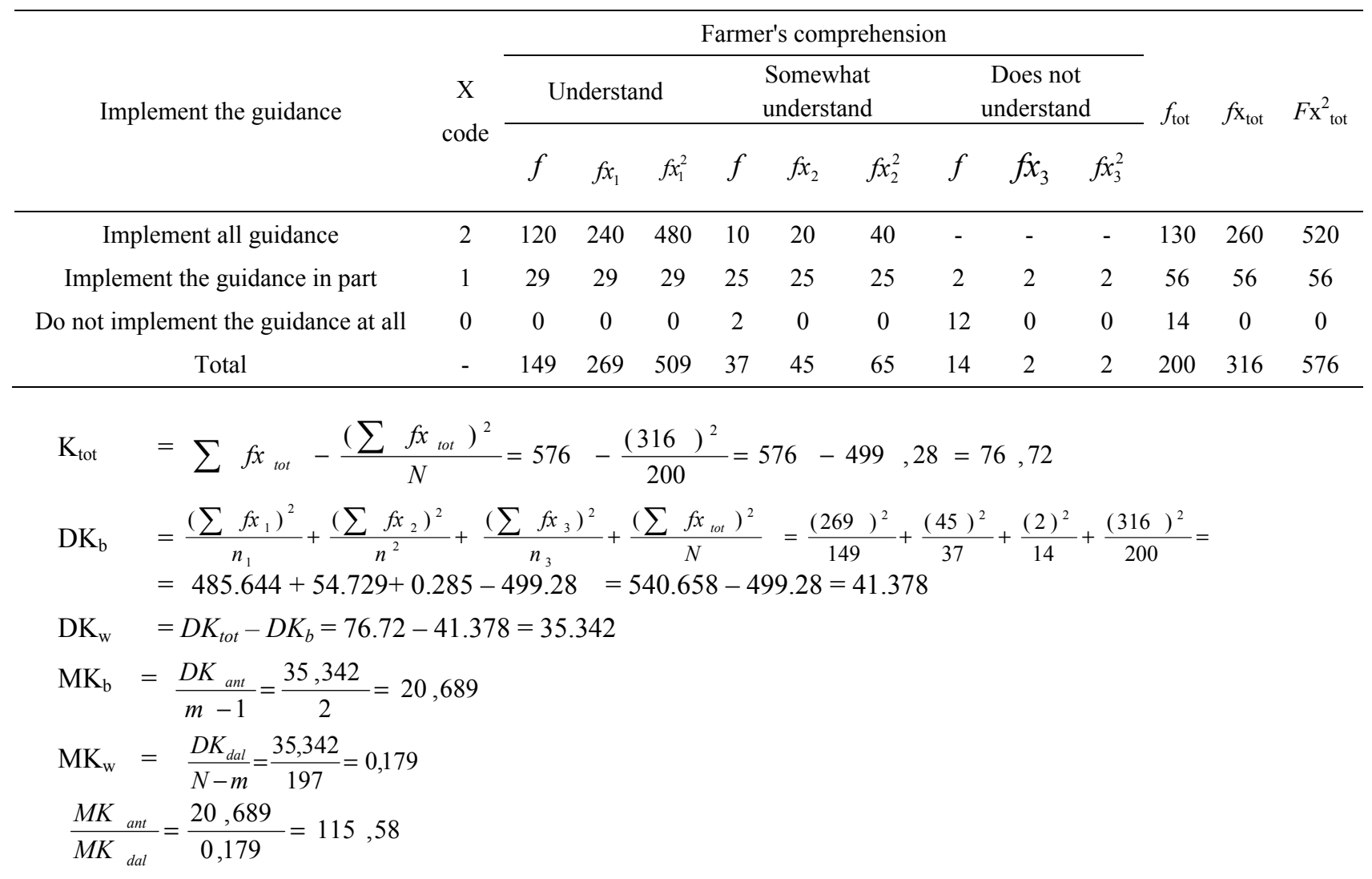

Table 9. ANOVA summary table based on the data in Table 8

\begin{tabular}{lcccccc}
\hline Sources of variation & $\mathrm{db}$ & $\mathrm{DK}$ & $\mathrm{MK}$ & $\mathrm{F}_{\mathrm{o}}$ & $\mathrm{F}_{\mathrm{t}}$ & Significance \\
\hline Intergroup & 2 & 41.378 & 20.689 & & $5 \%$ & Significant \\
& & & & 115.58 & 3.04 & $1 \%$ \\
In-group & 197 & 35.342 & 0.179 & & 4.71 & Significant \\
Total & 199 & 76,720 & - & - & - & - \\
\hline
\end{tabular}

Since the calculated $\mathrm{F}_{\mathrm{o}}(115.58)$ is higher than theoretical $\mathrm{F}$ either in significance level of 5\% (3.04) or significance level of $1 \%$ (471), null hypothesis stating that: "There is no influence between comprehension given by the counseling and implementation of guidance given by the counseling which is executed by participants of agricultural modernization" is rejected.

It means that implementation of guidance given by the counseling of agricultural modernization is highly determined by comprehension of the involved farmers. 
Table 10. Relationship between implementation of guidance given by the counseling and achieved result

\begin{tabular}{ccccc}
\hline \multirow{2}{*}{ Achieved Result } & \multicolumn{4}{c}{ Implementation of guidance } \\
\cline { 2 - 4 } & Implement all guidance & Implement guidance in part & Do not implement guidance at all & Amount \\
\hline Increasing & 120 & 10 & - & 130 \\
It's all the same & 29 & 25 & 2 & 54 \\
Decreasing & - & 2 & 12 & 14 \\
\hline Total & 130 & 56 & 14 & 200 \\
\hline
\end{tabular}

Table 11. Worksheet to calculate $\mathrm{f}_{\mathrm{o}}$

\begin{tabular}{|c|c|c|c|c|c|c|c|c|c|c|c|c|c|}
\hline \multirow{3}{*}{ Achieved result } & \multirow{3}{*}{$\begin{array}{c}\mathrm{X} \\
\text { code }\end{array}$} & \multicolumn{9}{|c|}{ Implementation of the guidance } & \multirow{3}{*}{$f_{\text {tot }}$} & \multirow{3}{*}{$f \mathrm{x}_{\mathrm{tot}}$} & \multirow{3}{*}{$F \mathrm{x}_{\text {tot }}^{2}$} \\
\hline & & \multicolumn{3}{|c|}{$\begin{array}{l}\text { Implement all } \\
\text { guidance }\end{array}$} & \multicolumn{3}{|c|}{$\begin{array}{c}\text { Implement guidance } \\
\text { in part }\end{array}$} & \multicolumn{3}{|c|}{$\begin{array}{c}\text { Do not implement } \\
\text { guidance at all }\end{array}$} & & & \\
\hline & & $f$ & $f x_{1}$ & $f x_{1}^{2}$ & $f$ & $f x_{2}$ & $f x_{2}^{2}$ & $f$ & $f x_{3}$ & $f x_{3}^{2}$ & & & \\
\hline $\begin{array}{l}\text { Implement all } \\
\text { guidance }\end{array}$ & 2 & 120 & 240 & 480 & 20 & 40 & 80 & - & - & - & 140 & 280 & 560 \\
\hline $\begin{array}{c}\text { Implement } \\
\text { guidance in part }\end{array}$ & 1 & 8 & 8 & 8 & 28 & 28 & 28 & 13 & 13 & 13 & 49 & 49 & 49 \\
\hline $\begin{array}{l}\text { Do not implement } \\
\text { guidance at all }\end{array}$ & 0 & 2 & 0 & 0 & 8 & 0 & 0 & 1 & 0 & 0 & 11 & 0 & 0 \\
\hline Total & - & 130 & 248 & 488 & 56 & 68 & 108 & 14 & 13 & 13 & 200 & 329 & 609 \\
\hline
\end{tabular}

$$
\begin{aligned}
\mathrm{DK}_{\text {tot }} & =\sum f x_{\text {tot }}^{2}-\frac{\left(\sum f x_{\text {tot }}\right)^{2}}{N}=609-\frac{(329)^{2}}{200}=609-541,205=67,775 \\
\mathrm{DK}_{\mathrm{b}} & =\frac{\left(\sum f x_{1}\right)^{2}}{n_{1}}+\frac{\left(\sum f x_{2}\right)^{2}}{n^{2}}+\frac{\left(\sum f x_{3}\right)^{2}}{n_{3}}+\frac{\left(\sum f x_{\text {tot }}\right)^{2}}{N}=\frac{(248)^{2}}{130}+\frac{(68)^{2}}{56}+\frac{(13)^{2}}{14}+\frac{(239)^{2}}{200}= \\
& =473.108+82.571+12.071-541.205=567.889-541.205=26.684 \\
\mathrm{DK}_{\mathrm{w}} & =D K_{\text {tot }}-D K_{b}=67.795-26.684=41.111 \\
\mathrm{MK}_{\mathrm{b}} & =\frac{D K_{a n t}}{m-1}=\frac{26,684}{2}=13,342 \\
\mathrm{MK}_{\mathrm{w}} & =\frac{D K_{d a l}}{N-m}=\frac{41,111}{197}=0,209 \\
\frac{M K_{a n t}}{M K_{d a l}} & =\frac{13,342}{0,209}=63,837
\end{aligned}
$$

Table 12. ANOVA summary table based on the data in Table 11

\begin{tabular}{ccccccc}
\hline Sources of variation & $\mathrm{db}$ & $\mathrm{DK}$ & $\mathrm{MK}$ & $\mathrm{F}_{\mathrm{o}}$ & $\mathrm{F}_{\mathrm{t}}$ & Significance \\
\hline Intergroup & 2 & 26.684 & 13.342 & & $5 \%$ & Significant \\
& & & & 63.837 & 3.04 & $1 \%$ \\
In-group & 197 & 41.111 & 0.209 & & 4.71 & Significant \\
Total & 199 & 67.795 & - & - & - & - \\
\hline
\end{tabular}

If the calculated $\mathrm{F}_{\mathrm{o}}(63.837)$ is higher than theoretical $\mathrm{F}$ either at significance level of 5\% (3.04) or significance level of $1 \%$ (4.71), null hypothesis stating that: "There is no significant influence between implementation of guidance on agricultural modernization and result achieved by the farmers" and "There is no significant influence between implementation of agricultural modernization and result achieved by the farmers" are rejected.

Thus, it means that implementation of technical guidance on agricultural modernization determines the result achieved by farmers who are involved in agricultural modernization. It also means that if the guidance given by officers of agricultural modernization is implemented, harvest of the farmer will increase. 
Table 13. Relationship between motives in attending at counseling and frequency in participating at the counseling of agricultural modernization

\begin{tabular}{|c|c|c|c|c|c|c|c|c|c|c|}
\hline \multirow{3}{*}{$\begin{array}{l}\text { Attendance at the Counseling } \\
\text { Agricultural modernization }\end{array}$} & \multicolumn{8}{|c|}{ Motives } & \multirow{2}{*}{\multicolumn{2}{|c|}{ Amount }} \\
\hline & \multicolumn{2}{|c|}{ Self-awareness } & \multicolumn{2}{|c|}{ By the order } & \multicolumn{2}{|c|}{ Friend's call } & \multicolumn{2}{|c|}{ Never } & & \\
\hline & $\mathrm{f}$ & $\%$ & $\mathrm{f}$ & $\%$ & $\mathrm{f}$ & $\%$ & $\mathrm{f}$ & $\%$ & $\mathrm{~F}$ & $\%$ \\
\hline Always & 86 & 43 & 30 & 15 & 6 & 3 & - & - & 122 & 61 \\
\hline Sometimes & 28 & 14 & 20 & 10 & 16 & 8 & - & - & 64 & 32 \\
\hline Never & - & - & - & - & - & - & 14 & 7 & 14 & 7 \\
\hline Total & 144 & 57 & 50 & 25 & 22 & 11 & 14 & 7 & 200 & 100 \\
\hline
\end{tabular}

Among 200 respondents (farmers participated at the agricultural modernization), in fact:

- 114 people $(57 \%)$ are participating at the counseling of agricultural modernization by their self-awareness; a number of 86 people (43\%) always attend the counseling and the other 28 people (14\%) attend the counseling every once in a while.

- There are 50 people (25\%) who participate in the counseling by the order; 30 people (15\%) among them always attend the counseling, while another 20 people (10\%) comes on occasion.

- There are 22 people (11\%) who participate in the counseling by friend's call; among these people, 6 people (3\%) always attend the counseling and another 16 people (8\%) sometimes come.

- The remaining respondents of 14 people (7\%) clarify that they had never come to the counseling.

Table 14. Approach method of agricultural modernization applied by the officer is connected to farmer's educational background

\begin{tabular}{|c|c|c|c|c|c|c|c|c|}
\hline \multirow{3}{*}{ Educational background } & \multicolumn{6}{|c|}{ Approach method } & \multirow{2}{*}{\multicolumn{2}{|c|}{ Amount }} \\
\hline & \multicolumn{2}{|c|}{ Lecturing method } & \multicolumn{2}{|c|}{ Demonstration plot method } & \multicolumn{2}{|c|}{ Grouping method } & & \\
\hline & $\mathrm{f}$ & $\%$ & $\mathrm{f}$ & $\%$ & $\mathrm{f}$ & $\%$ & $\mathrm{f}$ & $\%$ \\
\hline Illiterate & 15 & 7.5 & 20 & 10 & 40 & 20 & 75 & 37.5 \\
\hline Elementary school & 22 & 11 & 45 & 22.5 & 8 & 4 & 75 & 37.5 \\
\hline Junior high school or above & 40 & 20 & 10 & 5 & - & - & 50 & 25 \\
\hline Total & 77 & 38.5 & 75 & 37.5 & 48 & 24 & 200 & 100 \\
\hline
\end{tabular}

Among 200 respondents (farmers participated in agricultural modernization), here are the facts:

- There are 77 people (38.5\%) who begin to join agricultural modernization by the time giving command/lecturing method is conducted by officer; 40 people $(20 \%)$ have educational background from junior high school or above, 22 people (11\%) are educated by elementary school and the remaining 15 people $(7.5 \%)$ are illiterate. It indicates that the method is not suitable for farmers with low educational background or even illiterate people.

- There are 75 people $(37.5 \%)$ who begin to join agricultural modernization after knowing the result of demonstration plot method, i.e. 20 people $(10 \%)$ are illiterate, 45 people $(22.5 \%)$ are educated by elementary school, and the remaining 10 people $(5 \%)$ are educated by junior high school or above.

- Based on the numeral data in table above, demonstration plot method is suitable for farmers with elementary educational background.

- Among 48 people (24\%) participating in agricultural modernization after practicing farmers group, 40 people $(20 \%)$ are illiterate and the other 8 people $(4 \%)$ had educated in elementary school. In this group, there is no one have education background up to junior high school or above. It indicates that farmers group is more suitable to invite illiterate farmers to participate in agricultural modernization.

By the fact that farmers grouping method is suitable to invite illiterate farmers to participate in agricultural modernization, it indicates that by having farmers group, those farmers get guidance by their own language or from friends. Farmers group is led by member of their group who understands more about agricultural modernization. Agricultural extension channels agricultural modernization techniques to farmers through the leader of farmers group. 
Based on the fact of those three approach method to agricultural modernization, it will be better to apply them collectively for the success of agricultural modernization. For more details, look at the graphic below.

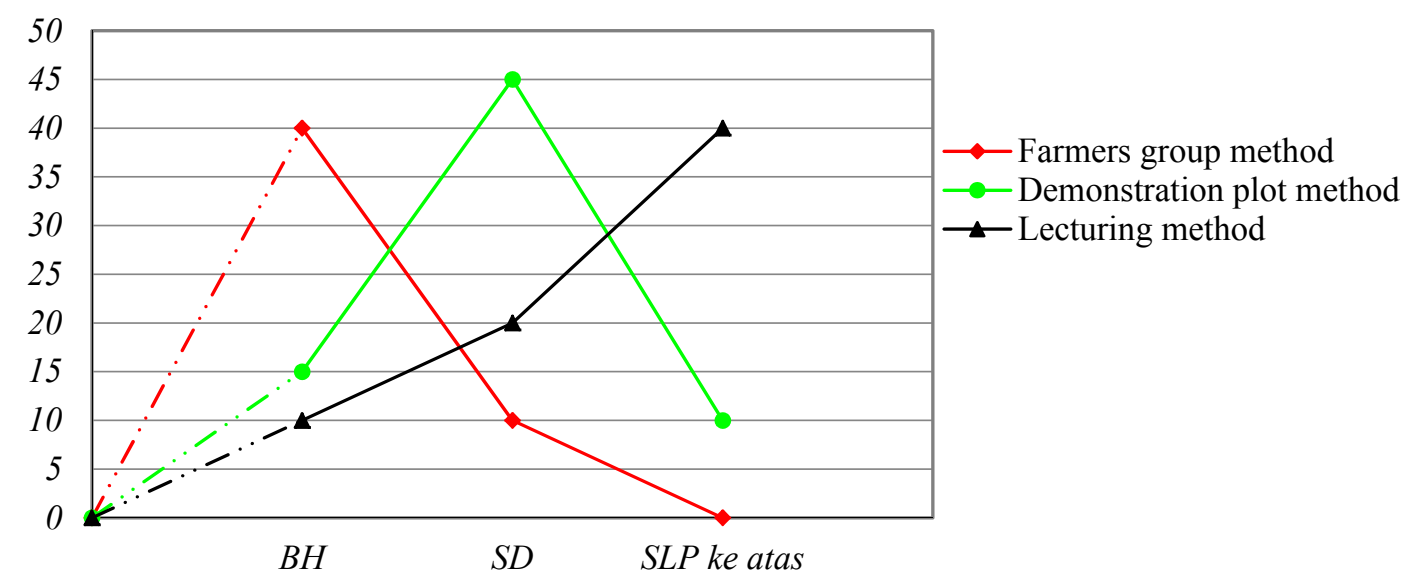

Figure 1. Approach method of agricultural modernization applied by the officer is connected to farmer's educational background in Anggeraja Sub-district

\section{Conclusion}

- Educated farmer performs more positive participation compared to uneducated farmers either in attending counseling or having awareness in operating instructions given by the officers.

- Both hypotheses are seen as hypothesis reflecting attitude of the farmers to agricultural modernization; in such way, hypothesis proposing that: "Success or failure of agricultural mechanization in Anggeraja Sub-district which is affected by attitude of farmers therein" is acceptable.

\section{References}

Achmad, S. (2005). Rencana Strategi Badan Litbang Pertanian. Jakarta, Badan Litbang Pertanian.

Anadki, E. C. (1971). Langkah-Langkah Penting Dalam Penyelenggaraan Demplot. Dinas Pertanian, Jakarta.

Badjuri, A. K, \& Yuwono, T. (2002). Kebijakan Publik, Konsep dan Strategi, Universitas Diponegoro Semarang.

Batten,T. R. (1969). Commnunities and Their Development.

Bonner, H. (1953). Social psychology. American Bolok Company, New York - Cincinnati - Chicago - Boston Atlanta Dallas - San Francisco.

Bungaran, S. (2004). Perkembangan Mutahir Pertanian Indonesia dan Agenda Pembangunan Ke Depan. Malang: Fakultas Pertanian Universitas Brawijaya.

Dunn, W. N. (2000). Introduction to Public Policy Analysis. Gajah Mada University Press, Yogyakarta

Freedman, R. (1969). Principles of Sociology. Trikarya Bhakti.

Gerungan, W. A. (1967). Psykhologi Sosial. PT Eresco, Bandung.

Hadi, S. (1970). Methodologi Research. Yayasan Penerbitan FIP-IKIP, Yogyakarta, Cetakan III.

Islamy, I. (2000). Prinsip-Prinsip Perumusan Kebijakan Publik. Bumi Aksara, Jakarta.

Keyfits, N., \& Nitisastro, W. (1964). Soal Penduduk dan Pembangunan Indonesia. PT Pembangunan, Jakarat.

Kindlebarger, C. P. (1969). Pembangunan Ekonomi; Terj. Hilman Surawiguna Cs PT Dian Rakyat, Jakarta, Moshe,A.T; Menggerakkan dan Membangun Pertanian; Sad. S.Krisnandhi, CV Yasaguna, Jakarta,

Lsmawan, B. (1972). Produksi \& Taraf Hidup Meningkat. Trubus, 36.

Mokodompit, E. A. (1963). Social Research Methodology. Gotong Royong, Makassar,

Molleong, L. J. (2001). Qualitative Research Methodology. PT. Remaja Rosdakarya, Bandung.

Mubyarto. (1972). Introduction to Agricultural Economics. Research Institute for Social and Economic Education; Yogyakarta. 
Muhadjir, N. (2000). Qualitative Research Methodology (4th ed.). Rake Sarasin, Yogyakarta.

National Library Foundation. (1975). News Social Science and Culture. Bulletin Yaperna; Jakarta.

Ridha, W. (1973). Introduction to Basic Research Type Prognostic. FIP- IKIP, Ujung Pandang.

Rijoatmodjo, S. (1960). Ethnologi. Prapanca, Yogyakarta,

Ronald, T. H. J. (1970). Pengantar Bimbingan \& Penyuluhan. FIP-IKIP, Makassar.

Soekanto, S. (1970). Sosiologi Suatu Pengantar. Yayasan Penerbit UI, Jakarta.

Soerjabrata, S. (1974). Psykhologi Kepribadian. Rake Press, Yogyakarta.

Tiffin, J., \& Ernest, J. M. C. (2009). Cormick; Industrial Psychology. Maruzen Asian Edition, Tokio-Japan.

Tilaar. (1972). Functions of National Education and Moral Development. Bulletin ISPPI, 1.

Toroncend, J. C. (1957). Introduction to Experimental Method. New York: American Book Company.

Wattimena, D. M. (1963). Faktor Psykhologis Memperlipat Gandakan Efisiensi Bekerja. PT Surungan, Jakarta.

Wibawa, S. (1997). Evaluasi Kebijakan Publik. PT. Raja Grafindo Jakarta.

Winarno, B. (1997). Teori Kebijakan Publik. PT.Citra Aditya Bakti, Bandung

\section{Copyrights}

Copyright for this article is retained by the author(s), with first publication rights granted to the journal.

This is an open-access article distributed under the terms and conditions of the Creative Commons Attribution license (http://creativecommons.org/licenses/by/3.0/). 